\title{
Study on seed priming methods on growth, seed yield and production economics of desi chickpea
}

\author{
Jamkhogin Lhungdim*, K. Nandini Devi, Yumnam Sanatombi Devi and Y. Bebila Devi \\ Department of Agronomy, College of Agriculture, Central Agricultural University, Iroisemba, Imphal (Manipur) India \\ (Email: ginlhungdim@rediffmail.com)
}

\begin{abstract}
A field trial to evaluate the effects of priming methods and sowing depth of desi chickpea variety JG-14 was conducted at College of Agriculture, CAU, Imphal (Manipur) during Rabi season of 2014-15 and 2015-16 with two factors viz., priming methods (Distilled water, Mannitol, $\mathrm{NaCl}$ and $\mathrm{KNO}_{3}$ ) and sowing depth $(5 \mathrm{~cm}, 7.5 \mathrm{~cm}$ and $10 \mathrm{~cm}$ ). Hydro-primed seeds of chickpea sown at $10 \mathrm{~cm}$ recorded significantly highest growth parameters, yield attributes and seed yield $(852.73 \mathrm{~kg} / \mathrm{ha}$ ) while lowest grain yield was recorded in $\mathrm{NaCl}$ primed seeds with $5 \mathrm{~cm}$ sowing depth. Higher root length and root dry matter were obtained from the plants primed with $\mathrm{KNO}_{3}$ with sowing depth of $7.5 \mathrm{~cm}$ while hydro-primed seeds sown at $5 \mathrm{~cm}$ exhibited earliest germination while hydro-primed seeds sown at $10 \mathrm{~cm}$ recorded the highest field emergence (75.42\%). Highest net return and B:C ratio (1.38) was obtained with hydro-priming and sowing depth of $10 \mathrm{~cm}$ which be recommended for desi chickpea in North eastern region.
\end{abstract}

Key Words : Chickpea, Growth, Seed priming, Sowing depth, Yield

View Point Article : Lhungdim, Jamkhogin, Devi, K. Nandini, Devi, Yumnam Sanatombi and Devi, Y. Bebila (2019). Study on seed priming methods on growth, seed yield and production economics of desi chickpea. Internat. J. agric. Sci., 15 (1) : 37-42, DOI:10.15740/HAS/IJAS/ 15.1/37-42. Copyright@2019: Hind Agri-Horticultural Society.

Article History : Received : 11.07.2018; Revised : 20.11.2018; Accepted : 26.11.2018

* Author for correspondence: 